\title{
Dumas en caricatures, dir. J. ANSELMINI et I. SAFA
}

\section{Lise Sabourin}

\section{(2) OpenEdition \\ Journals}

Édition électronique

URL : https://journals.openedition.org/studifrancesi/31988

DOI : 10.4000/studifrancesi.31988

ISSN : 2421-5856

\section{Éditeur}

Rosenberg \& Sellier

Édition imprimée

Date de publication : 1 août 2020

Pagination : 423

ISSN : 0039-2944

Référence électronique

Lise Sabourin, «Dumas en caricatures, dir. J. AnSELminı et I. SAFA », Studi Francesi [En ligne], 191 (LXIV | II) | 2020, mis en ligne le 01 septembre 2020, consulté le 17 septembre 2021. URL : http://

journals.openedition.org/studifrancesi/31988; DOI : https://doi.org/10.4000/studifrancesi.31988

Ce document a été généré automatiquement le 17 septembre 2021.

\section{(c)}

Studi Francesi è distribuita con Licenza Creative Commons Attribuzione - Non commerciale - Non opere derivate 4.0 Internazionale. 


\title{
Dumas en caricatures, dir. J. ANSELMINI et I. SAFA
}

\author{
Lise Sabourin
}

\section{RÉFÉRENCE}

Dumas en caricatures, dir. J. ANSELMINI et I. SAFA, “Cahiers Dumas" 45, 2019, 201 pp.

1 Julie Anselmini et Isabelle Safa introduisent (pp.13-23) ce $45^{\mathrm{e}}$ numéro des "Cahiers Dumas" consacré à Dumas en caricatures. Outre leurs aspects techniques, leurs enjeux esthétiques et leur dimension politique, elles précisent combien le personnage de Dumas par sa truculence, ses amours à scandale, sa physionomie singulière, les caractères hauts en couleurs des personnages qu'il a inventés, a nourri cet art, éminemment populaire tout comme ses romans.

2 Suivent donc cinquante-sept caricatures parues notamment dans la petite presse, de 1835 à 1952, date de tombée dans le domaine public de ses œuvres, présentées et commentées par Anne-Marie CALLET-BIANCO, Barbara COOPER, Jacqueline RAZGONNIKOFF et Claude schopp, qui fournissent aussi en fin de volume un dictionnaire des caricaturistes concernés. Des portraits-charges à la course au clocher académique, des dessins pleins d'humour de Cham et Marcelin aux planches suscitées par les impressions de voyages et les conférences dumasiennes, le lecteur de cette revue s'amuse en effet beaucoup à voir ainsi s'élaborer le mythe dumasien. 